\title{
Media, independent non-executive directors and strategy disclosure by non-financial listed firms in the UAE
}

\section{Mostafa Kamal Hassan and Fathia Elleuch Lahyani}

\author{
Mostafa Kamal Hassan and \\ Fathia Elleuch Lahyani are \\ both based at the \\ Department of Accounting \\ and Information Systems, \\ College of Business and \\ Economics, Qatar \\ University, Doha, Qatar.
}

Received 18 January 2019

Revised 19 June 2019

18 September 2019

6 October 2019

14 October 2019

Accepted 15 October 2019

(C) Mostafa Kamal Hassan and Fathia Elleuch Lahyani. Published by Emerald

Publishing Limited. This article is published under the Creative Commons Attribution (CC BY 4.0) licence. Anyone may reproduce, distribute, translate and create derivative works of this article (for both commercial and non-commercial purposes), subject to full attribution to the original publication and authors. The full terms of this licence may be seen at http://creativecommons. org/licences/by/4.0/legalcode

\begin{abstract}
Purpose - This study aims to investigate the effect of media coverage, negative media tone and the interaction between negative media tone and independent non-executive directors (INEDs) on strategic information disclosure (SD).
\end{abstract}

Design/methodology/approach - The authors rely on media agenda-setting theory, agency theory and a panel data set of 52 UAE non-financial listed firms from 2009 to 2016. Multivariate regressions examine the effect of media coverage and negative media tone on SD and examine the moderation of INEDs on the effect of negative media tone on SD while controlling for firm size, board size, board meeting frequency, firm profitability and leverage.

Findings - The results show that negative media tone has a negative effect on SD, and there is no association between media coverage and SD. The results show that INEDs are negatively associated with $S D$ and have a negative moderating effect on the negative media tone-SD relationship. INEDs follow a conservative approach, encouraging less SD when their firms face negative media tone.

Research limitations/implications - The authors measured media coverage and negative media tone by the number of news articles. In the robustness test, they use media tone score. They measured SD using an index that captures firm strategy dimensions. Though these measures are inherently subjective, they were used to measure variation in media coverage, media tone and SD across listed UAE nonfinancial firms. Mitigation of subjectivity was achieved through rigorous cross-checking measurements.

Practical implications - Findings assist UAE policymakers and the international business community with insights related to articulation of media to SD and INEDs' role in moderating the effect of media on SD.

Originality/value - To the authors' knowledge, this is the first study that combines media agenda-setting theory with agency theory and SD in an emerging market economy (the UAE). The study is also among the few studies that illustrate the possible role of INEDs under different media tones in emerging markets.

Keywords Agency theory, Strategic disclosure, Media coverage, Media agenda-setting theory, Media tone

Paper type Research paper

\section{Introduction}

Strategic information disclosure (SD) is a voluntary means firms frequently use to distinguish themselves from their competitors and disseminate information about their mission, vision, market, customers, plans and strategic goals (Santema and Van de Rijt, 2001; Santema et al., 2005; Lim et al., 2007; Hassan, 2015a, 2015b). Such information is used by a firm's external constituents (i.e. customers, investors, legislators, public and media) in their decisions. The literature in SD has witnessed an increasing number of studies investigating the effect of firms' governance structure on the disclosure of strategic information on the internet (García-Sánchez et al., 2011; Hashim et al., 2014; Hassan, 2015a, 2015b), while other studies examine strategic information reported in mission statements and firms' annual reports (Leuthesser and Kohli, 2001; Bartkus et al., 2002; Campbell et al., 2001). 
Although SD studies are conducted in different contexts (Santema and Van de Rijt, 2001; García-Sánchez et al., 2011 [Spain]; Santema et al., 2005 [EU]; Hashim et al., 2014 [Malaysia]; Hassan, 2015a, 2015b [UAE]), they are mostly informed by agency theory, reasoning that disclosure reduces information asymmetry and agency costs.

Most prior SD studies focused on exploring the influence of governance structure and firmspecific characteristics, including size, board composition, ownership structure, board meeting frequency, audit committee, firm complexity, leverage and profitability on the extent of SD (García-Sánchez et al., 2011; Hashim et al., 2014; Hassan, 2015a, 2015b) and neglected media's influence (as an institutional governance mechanism) on firms' SD. While growing research examines the role of media (coverage and tone) on corporate disclosure, this research focuses on the disclosure of social and environmental information (Islam and Deegan, 2010; Cuadrado-Ballesteros et al., 2014; Garcia-Sanchez et al., 2014; Rupley et al., 2012; Elijido-Ten, 2011), which makes examining the media-SD association an underresearched area, particularly in emerging markets.

A closer analysis of governance-SD studies reveals their focus on documenting the association between board composition and SD while ignoring board members' behavior when their firms face positive or negative media coverage. Their underlying rationale is that board of directors' composition in terms of a higher percentage of independent nonexecutive external directors (INEDs) guarantees quality disclosure (Rupley et al., 2012; Garcia-Sanchez et al., 2014; Zaman et al., 2018). INEDs monitor and control inside directors' actions and offset their opportunistic behaviors (Zaman et al., 2018). They provide outside perspectives to help firms achieve their strategic goals (Ibid.,). They have strong stakeholder orientations and a high level of engagement that goes beyond shareholders to include constituents such as the public, media, legislators, and those with legitimate interests in the firm's activities (Rupley et al., 2012; Garcia-Sanchez et al., 2014). Rupley et al. (2012) argue that INEDs help in managing the firm's relationships with external constituents (e.g. media). Zaman et al. (2018) add that INEDs are experienced professionals who bring the independence that carries a superior objective to monitor management behavior by disclosing information. INEDs are partially motivated by monetary incentives and look to enhance and protect their personal reputations (Ibid.). Our study, therefore, focuses on INEDs and their moderating effect on the association between media and SD.

Our study examines the effect of media (coverage and negative media tone) on SD through a lens which combines notions of media agenda-setting theory and agency theory. Our study contributes to the existing literature in several ways. First, it pioneers the articulation of SD with media measures. Second, it integrates media agenda-setting theory with agency theory to examine SD in an emerging capital market (the UAE). In this regard, our study adds to prior studies which relied on media agenda-setting theory since they mainly investigated the disclosure of social and environmental information (Islam and Deegan, 2010; Cuadrado-Ballesteros et al., 2014; Garcia-Sanchez et al., 2014; Rupley et al., 2012; Elijido-Ten, 2011). Finally, our study acknowledges media's role (as an institutional governance mechanism) and investigates INEDs' role in moderating the association between media and SD.

There are several reasons to choose the UAE for this study. First, the UAE owns diverse influential media outlets which serve as a regional media hub (Johnson, 2015). The country established the National Media Council (NMC), which sets guidelines for electronic media and news on websites, supports media in delivering responsible and professional material, and ensures preserving local social values and culture (NMC No 11 of 2016, WAM news agency, 6 March 2018) (National Media council, 2018). There is public trust in analytical local media content, with a confidence level of about 78.7 per cent (AL Bawaba, 2017). This media environment provides an attractive opportunity to examine the association between $\mathrm{SD}$ and media coverage and tone in the UAE, while relying on media agenda-setting theory 
to underscore drivers and processes of firms' legitimacy, which is rarely used in emerging economies.

Second, the UAE is highly ranked in the World Economic Forum's Global Competitiveness Report (2017-2018). That status not only affects UAE non-financial firms' strategic planning; it also induces most firms to disclose strategic information to meet expectations of the international community and investors. The UAE aspires to establish itself as a global capital market and gain international investors' trust following the 2008 global financial crisis (Irvine, 2008; Hassan, 2014). Following the crisis, UAE firms want to consolidate their strategic vision to align with the country's large strategic projects and developments such as Expo 2020.

Finally, although the UAE has a code of governance delineating the role of directors (executive and independent non-executive), the role of executive directors has been undermined because of the lack of separation between ownership and management in emerging economies (Hassan, 2018). This brings the role of INEDs to the fore since they may behave differently under media pressure to keep their reputations and their future prospects for future directorship positions while monitoring and controlling the actions of inside directors (Zaman et al., 2018). INEDs represent one governance mechanism, yet they may act to protect their reputation by serving the interest of the firm's stakeholders. Our study, therefore, contributes to the role INEDs may play in emerging markets by examining their moderating effect on the association between negative media tone and SD.

The study is organized into eight sections. After this introduction, Section 2 reviews prior studies. Sections 3 and 4 discuss the study's theoretical framework and the UAE's institutional context. Section 5 discusses hypotheses development, and Section 6 discusses the study methodology. Section 7 presents the empirical findings and their robustness before the conclusion in Section 8 .

\section{Literature review}

The forthcoming analysis reviews prior studies while illustrating our study's contribution to existing literature. Santema and Van de Rijt (2001) examined SD in the annual reports of 73 Dutch listed companies for two years and concluded that Dutch firms are reluctant to disclose future strategies and forward-looking action plans. Padia and Yasseen (2011) analyzed the strategy disclosure of a sample of 100 listed firms of the South Africa Stock Exchange and found that large firms disclose more strategy-related information in annual reports. Santema et al. (2005) found that national-level divergence in corporate governance and cultural disparities affects the amount of SD across five European countries (the UK, The Netherlands, Germany, France and Poland).

García-Sánchez et al. (2011) examined the effect of corporate governance on SD in a sample of 117 Spanish listed companies. They found that CEO duality and less-frequent board meetings led to a higher level of SD on websites. Hashim et al. (2014) investigated determinants of SD in a sample of 165 Malaysian listed firms from 11 sectors. They found that Malaysian firms generally communicate a low volume of voluntary strategic information. Hashim et al. (2014) showed that board size influences levels of SD, yet board meeting frequency, institutional ownership and non-executive directors were not significant predictors. Hassan (2015a, 2015b) examined the effect of internal governance mechanisms and quality of the audit committee on SD on the internet in a sample of non-financial firms listed in the UAE stock market and demonstrated that the level of online reporting of SD is negatively correlated with the frequency of board of directors meetings.

Based on media agenda-setting theory, Deegan and Brown (1998) examined the relationship between print media and environmental disclosure in Australia. Their study examined the management response to media coverage of industry's environmental effects. They argued that media coverage drives community expectations, and hence, 
management responses by increasing the amount of environmental information in annual reports. They concluded that higher negative media coverage stimulates high levels of corporate environmental disclosure. Likewise, Deegan et al. (2000) found that major harmful environmental incidents attract more media attention, which in turn, motivates managers to disclose further environmental information to mitigate damages to firm image. Islam and Deegan (2010) examined changes in social and environmental disclosure practices of two multinational companies operating in developing countries and found that negative global news coverage (related to workplace safety and labor rights) shapes expectations of the global community. In response to global media, multinational companies reported more voluntary social responsibility disclosure to reduce the negative effect of media.

Rupley et al. (2012) investigated the relationship between governance mechanisms, media attention and the quality of environmental disclosure. Their results indicate the positive influence of negative media coverage on voluntary environmental disclosure in a sample of 127 US industrial firms listed in the period 2000-2005. Furthermore, under unfavorable media pressure, managers respond by increasing the volume and quality of environmental disclosures to legitimize corporate activities. The study also reported that board independence, size and gender diversity are positively related to environmental disclosure. Our study extends on the work of Rupley et al. (2012) by examining the moderating effect of INEDs on media-SD while testing the INEDs reaction under negative media coverage in emerging market context (the UAE).

In the Malaysian context, Elijido-Ten (2011) investigated the influence of media coverage and corporate governance on voluntary environmental disclosure, revealing that media coverage determines management disclosure strategy in response to unfavorable media. Elijido-Ten (2011) relied on the stakeholder theory in conjunction with media agenda setting theory to gain insights into the type of environmental disclosure strategy preferred by management. She measured media by relevant media websites/reports pointing to "hot topics" related to Malaysian environmental issues, while conducting interviews to explore stakeholders' reaction to negative environmental events took place at the time of the study. Elijido-Ten (2011) provided evidence documenting that the influence of media coverage on management's preferred disclosure strategy is noticeable when the event is of a negative nature. Our study uses a combined lens integrating agency theory with media agenda setting theory to examine media-SD relationship, and the moderating role which INEDs play under negative media coverage in the UAE. Our study also uses different media measures and random effects regressions which have not been utilized addressed by Elijido-Ten (2011) study.

Cuadrado-Ballesteros et al. (2014) examined the impact of media pressure on sustainability disclosure in a sample of 102 large municipalities in Spain during 2011. Their results showed an inverse relationship between media coverage and sustainability disclosure, regardless of the nature of news: negative, positive or neutral. They also reported that under unfavorable media attention, politicians in local municipalities tend to conceal information that does not match community expectations. Our study adds to Cuadrado-Ballesteros et al. (2014) study in number of ways. Our study examines the effect of on SD relationship in the UAE non-financial sector. It also investigates the effect of the interaction between negative media and INEDs on SD using a panel data covering a longer timeframe (20062016). Furthermore, our study uses different media proxies (media coverage; media tone, negative media) instead of using a single media measure measured by total number of articles determined by Google.

Garcia-Sanchez et al. (2014) investigated the influence of media pressure and board composition on corporate social responsibility (CSR) disclosure for a sample of 98 nonfinancial listed Spanish fimrs. They found that under increasing media pressure, firms are likely to disclose more information regarding their social and environmental performance. The study findings also indicate that firms use CSR disclosure to respond to community 
expectations. Our study shares some similarities with Garcia-Sanchez et al. (2014), yet it differs in number of aspects. Our study examines the association between media and SD instead of CSR disclosure, and how the interaction between INEDs and negative media may affect SD. Garcia-Sanchez et al. (2014) did not examine the joint effect of negative media and INEDs, they examined the interaction between media intensity (measured by Google News items per year about the firm) and the independent directors. In this regard, our study transcends Garcia-Sanchez et al.'s (2014) study and uses three different media measures: media coverage measured by total press articles about firm $\mathrm{i}$ in year $t$, media tone measured by total number of positive press articles minus total number of negative press articles for the year $t$ scaled by total number of press articles during year $t$; and negative media coverage measured by the total number of negative news articles on firm i during year t. Finally, our study examines media-SD in emerging market (the UAE), which is different from the context of Garcia-Sanchez et al. (2014) study capital market (Spain).

Zaman et al. (2018) examined the impact of corporate governance and media coverage on corporate disclosure in a sample of 99 firms listed on Pakistan's stock exchange over the period 2007-2012. They found that media and independent directors play a significant positive role in enhancing corporate disclosure, highlighting that under intense media coverage, independent directors become risk-averse and therefore hold information to protect their reputation. Like Garcia-Sanchez et al. (2014), Zaman et al. (2018) did not examine the interaction between negative media and INEDs and its effect on the corporate disclosure. Zaman et al. (2018) also used fixed effects regressions to test the relationship between governance, media coverage and corporate transparency despite the low variability in their study governance variables. Our study exceeds Zaman et al. (2018) study by addressing the effect of the interaction between negative media and INEDs on SD using random effects regressions. Furthermore, our study utilizes different media measures (media tone, total number of articles and total number of negative articles) while Zaman et al. (2018) used only one media measure (total number of articles per year).

The above analysis highlights the contributions of our study. On the one hand, prior SD studies examined the effect of corporate governance on SD and neglected media's effect on SD. On the other hand, disclosure-based media agenda-setting theory studies examine the effect of media, mainly on corporate social and environmental disclosure, in Western and European contexts (US, Spain, Australia, and UK). Our study, therefore, adds to prior studies by underscoring the effect of media on SD and examining INEDs' moderating role on the media-SD relationship in an emerging market context (the UAE) which, to the authors' knowledge, has not been done.

\section{Theoretical framework}

Our study relies on both agency theory and media agenda-setting theory. According to agency theory, media can serve to reduce "information asymmetry" between firm managers and external constituents (Bushee et al., 2010). Media contribute to enlightening the public on issues that would have been salient to the corporation's constituents (Bednar, 2012). Media is an important external governance mechanism that affects corporate disclosure along with internal governance mechanisms (Garcia-Sanchez et al., 2014; Zaman et al., 2018). Media shape a company's reputation and create pressure to disclose information, which reduces agency conflicts (Zaman et al., 2018). Although agency theory provides a platform to understand how media exert influence by monitoring firms, it lacks a less socially informed view of the media's role in corporate governance. In this regard, media agendasetting theory suggests that besides its monitoring role, media contribute to the legitimization processes of organizational activities, including disclosure (Watson, 2011).

According to media agenda-setting theory, the media influences society's values (Deegan and Brown, 1998; Watson, 2011). Society's expectations regarding topics, people and organizations are shaped by news, communiqués, and television. Media shape public 
opinion, social norms and values to which organizations must conform. Media influence the values and norms of stakeholders operating in and around a company. Meyer and Rowan (1977) argued that a corporation's survival and continuity depend on its ability to deliver desirable ends to different groups with an influence on the corporation's right to exist (Suchman, 1995; O'Donovan, 2002; Deegan, 2002; Milne and Patten, 2002; Mobus, 2005; Campbell, 2000; Dumay et al., 2015). The congruence between a corporation's value system and the media is becoming an increasingly important condition for companies' survival.

Media expresses public opinion and shape the opinion of stakeholders who eventually pressure companies to conform to media (e.g. by providing SD). Media pressure is a social and institutional force that forms social expectations. Media provide news and information that enables society to set an agenda of relevant issues, which implies that media coverage determines public, business and even political agendas (Carroll and McCombs, 2003). Moreover, media provides a platform for understanding the content of social discourse because it disseminates meaning, knowledge and information (Yekini et al., 2017). Media not only draws public attention to topics and issues of interest but also pressures organizations to conform to social expectations expressed in the media.

Along with being an institutional governance mechanism, media act as a "watcholog" of business activities since it attracts attention of firm' managers, its external constituents and the society in which it operates (Watson, 2011; Bednar, 2012). Media play an active role in disseminating information about firms and therefore draws decision makers' attention to topics which interest those with an interest in the firm's activities (Lui and McConnell, 2013). This attention-based view of decision-making lies at the heart of media agenda-setting theory. Because media influences internal (managers and employees) and external (customers, investors, and the public) stakeholders, there should be a relationship between media, as an external governance mechanism, and board composition, as an internal governance mechanism. Therefore, our study tests the influence of media tone - and the joint effect of media and board composition - on SD.

\section{The UAE institutional context}

The UAE has witnessed remarkable socio-economic growth in recent years, and the country has become a key focus for international investors (Hassan, 2014, 2015a, 2015b). The UAE actively seeks commercial partnerships with Western and European countries and maintains a strategy of "marketing the country as an attractive destination for business as well as residence" (Irvine, 2008, p. 126). As an emerging capital market with ambitious plans for international recognition, the UAE has engaged in huge strategic projects and developments such as Expo 2020. To achieve its 2021 vision, the UAE government announced number of strategic initiatives which focused on: strengthening CSR, promoting volunteerism, and reviewing public policies that facilitate the development of government partnerships with civil societies, media and businesses to ensure a concrete sustainable development (Almatrooshi et al., 2018).

The UAE adopts market-oriented economic policies based on economic diversification and international financial integration. The UAE's Worldwide Governance Indicators (WGI) rank high in terms of government effectiveness (90th percentile in 2016) and regulatory quality (80th percentile in 2016), revealing the credibility of government policies in stimulating the private sector (World Bank, 2016). The World Bank indicators also reflect the importance of country-level disclosure and transparency. According to the latest World Bank Ease of Doing Business report (2017) the UAE demonstrates a favoarable business environment, ranking 21st in 2017. The report highlights the high level of protection of minority shareholders' rights and the extent of corporate transparency. In fact, transparency and full disclosure are part of UAE regulators' agenda. The Emirates Security \& Commodity Market Authority's (ES\&CMA) listing conditions encourage firms to disclose their plans (UAE 
Federal Act No. 4 of 2000 and amendments of 2004). The UAE Minister of Economy and Planning describes the importance of full disclosure and transparency:

There is a need to improve levels of trust in the UAE market by further enhancing the role of law and voluntary disclosure (John, 2006).

The UAE Corporate Governance Code aligns country regulations with international best practices of governance (ES\&CMA decision R/32 of 2007 amended 2009). The Code underscores regulatory initiatives to ensure transparency and compels listed corporations to prepare, as an integral part of annual reports, a governance report. This report should outline, as the Code states, information regarding board of directors' duties, composition, structure, and selection process. Annual reports should also include information about board committees, internal control systems, directors' remuneration, risk management, shareholders' rights, and rules governing the appointment and discharge of external auditors (Hassan, 2012). The UAE's Code is the strictest across Gulf Cooperation Council (GCC) countries since it uses a comply/penalize approach, while other GCC countries use a comply/explain approach (Shehata, 2015).

A fundamental issue most Gulf States face is that firms are controlled by a few shareholders only (Baydoun et al., 2013); therefore, there is a rarely any separation between ownership and management. This situation undermines executive directors' role in monitoring and controlling firm activities. It brings INEDs' role to the fore since, to maintain their reputations and prospects for future directorship positions, they may behave differently under media pressure. This is combined with the difficulty in finding qualified and experienced INEDs because of the relatively small population of potential directors (Baydoun et al., 2013, p. 15).

As part of its institutional development, the UAE established the NMC to support all mediarelated activities. The Council ensures the execution of the best international standards related to media activities (Al Bawaba, 2017). In a study, NMC found that UAE media has gained the business community's trust (Al Bawaba, 2017). In 2007, the UAE Journalists Association published a Code of Ethics (Gulf News, 2007). UAE media agencies, such as Dubai Media, are committed to promoting a future national vision and promoting the country internationally (Al Bawaba, 2010). This shows that the country's media has a high level of professionalism and boosts the UAE's competitiveness. Furthermore, the UAE Constitution of 1971 protects the freedom of verbal and written opinion. Therefore, reporters have the freedom to express their views on issues except those that may affect national security (e.g. military secrets). Accordingly, the media is likely to manage the content of press reports to avoid violating legal restrictions. Because of the country's aspiration to be recognized globally, the media play an active role in both economic development and governance. The presence of professional media agencies not only fosters law-enforcing but also makes corporate managers and society vigilant to issues which would have been otherwise overlooked (Dash, 2012).

\section{Hypotheses development}

\subsection{Media coverage}

Studies have integrated media agenda-setting theory with accounting disclosure to investigate corporate management's communication with external audiences (Ader, 1995; Deegan and Brown, 1998; Deegan et al., 2000, 2002; O'Donovan, 2002). Their overall message is that corporate managers utilize disclosure to convince the public they are operating according to social expectations expressed in the media and to gain social legitimacy. Empirical studies have found that corporations with greater media coverage tend to disclose more information (Deegan and Brown, 1998; Patten and Nance, 1998; Bewley and Li, 2000; Garcia and Larrinaga, 2003; Reverte, 2009; Elijido-Ten, 2011). Media 
coverage creates community expectations that influence corporate managers (Nerlich and Halliday, 2007), who react by disclosing information to meet media pressure. Media disseminate information about company practices, strategies and plans, which reduces information asymmetry between managers and stakeholders and thus increases investors' and shareholders' trust (Garcia-Sanchez et al., 2014). We therefore argue that the volume of media coverage expresses social expectations regarding firms' strategic plans; hence, corporate managers respond by disclosing strategic information to obtain social legitimacy. Our first hypothesis is:

H1. The volume of media coverage is positively associated with SD.

\subsection{Media "tone"}

Although the volume of media coverage has been analyzed in prior studies, some scholars argue that "tone" is an important element of media coverage (Rupley et al., 2012; Chih and Chih, 2014; Aly et al., 2018). Aly et al. (2018) investigated the association between tone of narrative disclosure and firms' financial performance, concluding that a positive tone is positively associated with ROA, while a negative tone has a negative influence on firm performance. Du et al. (2016) examined the association between positive or negative media coverage and CSR measured by cash and goods donations to total assets (philanthropic giving). They found that negative media attention leads to an increase in donations. Cahan et al. (2015) found that positive media tone is positively related to firm CSR performance, meaning socially-oriented firms receive more favorable media coverage. Rupley et al. (2012) found no significant relation between positive or neutral media tone and environmental disclosure, yet found that negative media coverage significantly drives firms' managers towards environmental disclosure. Chih and Chih (2014) found a positive association between positive media tone and stock returns, while neutral and negative media coverage were not significant. We argue that to convince stakeholders that their strategic plans can overcome negative publicity; firms provide higher levels of SD when facing negative media. Our study therefore hypothesizes:

H2. Negative media "tone" coverage is positively associated with SD.

\subsection{Moderating effect of independent non-executive directors on media-strategic information disclosure relationship}

Prior studies examined the association between INEDs and SD (Hashim et al., 2014; García-Sánchez at al., 2011; Hassan, 2015a, 2015b), yet literature on the effect of the interaction betwen negative media tone and INEDs on SD is scarce. Garcia-Sanchez et al. (2014) examined the joint effect of media and percent of independent directors on CSR disclosure. They found that when firms face intense media coverage, independent directors provide less CSR disclosure because they fear that reacting to intensive publicity may bring bad news to the light and therefore damage their reputation in the labor market. Rupley et al. (2012) found that under negative media coverage, independent directors are reluctant to voluntarily disclose information, preferring to divert attention away from their companies and themselves. Concern over reputation gives INEDs an incentive to disclose less information (Garcia-Sanchez et al., 2014).

In contrast, Zaman et al. (2018) investigated the interaction between independent directors and media tone on corporate disclosure. They argue that negative media coverage pushes independent managers to behave more ethically and transparently (Dyck et al., 2008). Career-conscious directors are likely to support a greater volume of disclosure to preserve management value in the labor market (Lorsch and Young, 1990). Negative media coverage increases firms' visibility and hence, independent board members increase the level of disclosure to protect their public image (Zaman et al., 2018), improve their reputation with different stakeholders and facilitate promotions to directorship positions 
(Garcia-Sanchez et al., 2014). We argue, therefore, that INEDs moderate the effect of negative media coverage on SD. Since prior studies are inconclusive, our study proposes a non-directional hypothesis:

H3. INEDs moderate the effect of negative media tone on the level of SD.

\section{Methodology}

\subsection{Sample}

We drew a sample of 138 UAE firms listed in the Dubai Stock Market and Abu Dhabi Stock Market in 2016. Later, 86 firms were excluded because they do not provide SD, belong to the financial sector, or were delisted. Therefore, our final sample includes 52 non-financial firms and 404 firm-year observations for the period 2009-2016. Table I shows the industry profile of our sample, which is larger and covers a longer period than prior studies conducted in the UAE (Hassan, 2015a, 2015b; Adawi and Rwegasira, 2011). We extracted financial data from the Compustat database. Data related to SD and board composition were hand-collected from annual reports. Data were collected from four main sources: firms' annual reports; firms' governance reports; 3) Compustat database; and 4) Google search citations. Firms' annual reports were checked against the SD index (17 items, Appendix) used solely to measure variation in SD across the sample.

\subsection{Research design and variable measurements}

6.2.1 Strategic information disclosure index (dependent variable). Although there is no single definition of SD, several scholars indicate outlined elements of strategy-related information. For example, Lim et al. (2007) argued that non-financial information related to corporations' missions, visions, goals, outcomes, customers, markets and products is the most notable type of information firm managers communicate to stakeholders. SD has been defined as disclosure that covers dimensions such as firms' overall strategy, detailed future plans, mission, goals, and business units' strategy (Santema and Van de Rijt, 2001; Padia and Yasseen, 2011). Htay (2012) stated that SD also includes information on the firm's background, strategy, governance, and forward-looking planning. Hashim et al. (2014) argued that SD includes information enabling stakeholders to monitor and evaluate the company's position and performance. Hence, SD is a special type of voluntary disclosure a firm may use to disseminate information about its plans and strategic goals (Santema et al., 2005; García-Sánchez et al., 2011). Our study relies on the SD index proposed by Hassan (2015a, 2015b), who undertook an extensive review of studies to develop a list of SD index items (17 sentences) harmonized to the UAE context. We compared the contents of each firm's annual reports to the items in Appendix, which were coded as 1 if thematically disclosed, or 0 if not disclosed. Our study uses an unweighted index, as we do not focus on a particular user group, ascribing the same importance to all SD items.

\section{Table I Industry profile of the sample}

\begin{tabular}{lrr} 
Sector & Sample & (\%) \\
\hline Real Estate & 11 & 21.15 \\
Services & 5 & 9.62 \\
Oil and Energy & 2 & 3.85 \\
Materials, Industry and Construction & 15 & 28.85 \\
Technology and Telecommunications & 3 & 5.77 \\
Consumer Staples and Discretionary & 11 & 21.15 \\
Transportation & 5 & 9.62 \\
Total & 52 & 100
\end{tabular}


6.2.2 Statistical model and independent variables. The relationship between dependent and independent variables is tested through the model below:

$$
\begin{aligned}
\text { Strategic disclosure index }_{i t}= & \beta_{0}+\beta_{1} \text { Media coverage }_{i t}+\beta_{2} \text { INED }_{i t}+\beta_{3} \text { mediaxINED }_{i t} \\
& +\beta_{4} \text { Bsize }_{i t}+\beta_{5} \text { Bmeetings }_{i t}+\beta_{6} \text { Firmsize }_{i t}+\beta_{7} \text { Leverage }_{i t} \\
& +\beta_{8} R O E+\text { Year }_{t}+e_{i t}
\end{aligned}
$$

Table II summarizes the definition and measurement of each variable. We use panel data analysis to test the study hypotheses. Post-regression estimation tests reveal that the fixed effect model is a possible fit to our data set (Yekini et al, 2017). Based on prior studies of media coverage, media tone and firm-specific variables (García-Sánchez et al., 2011; Rupley et al., 2012; Garcia-Sanchez et al., 2014; Chih and Chih, 2014; Cahan, et al., 2015; Aly et al., 2018; Byun and Oh, 2018; Zaman et al., 2018), we investigate whether media coverage (volume), media tone (positive, neutral and negative) and the interaction between media tone and INEDs affect the level of SD by UAE listed non-financial firms.

For media coverage (volume), we used the Google News search tool to estimate the number of total number of local articles published in local press and newspapers for each year. This approach covers a wide range of local media coverage. It also returns specialized and non-specialized print press news (Garcia-Sanchez et al., 2014; CuadradoBallesteros et al., 2014; Zaman et al., 2018). We counted the total number of newspaper articles covering each firm per year to quantify overall media coverage. We included strategy- and non-strategy-related articles, because the number of articles devoted mainly to strategy is relatively small. Hence, media coverage (volume) was represented by the total number of news articles on non-financial listed firms between 1 January 2009 and 31 December 2016 as a proxy for overall media coverage.

Initially, we test the association between media coverage (volume), negative media tone and SD and examine whether INEDs play a moderating role on the media-SD relationship. We underscore negative media tone per year for each firm as the number of articles with a negative tone. We classify news articles into positive, neutral and negative. Following

\section{Table II Variable definitions and measurements}

Variables Definitions

Dependent variable

Strategic disclosure Disclosure index for corporate strategic information

score

Independent variables

Media coverage Natural logarithm $(1+$ total number of news articles about firm i in year $t)$

Negative media Natural logarithm (1+ negative media). Negative media is the total number of negative news articles on firm $\mathrm{i}$ during year $t$

Media tone score Total number of positive press articles news minus total number of negative press articles for the year $t$ scaled by total number of press news articles during year $t$ (used in robustness test)

INEDS Proportion of independent directors membership on the board (independent directors by board size)

INEDs $x$ negative Product of negative media measure and the proportion of INEDs on the board

media

Control variables

Board size

Number of directors on corporate board

Board meetings Number of board meetings during the year

Firm size

Profitability

Natural logarithm of total assets

Return on equity (net income divided by total equity)

Leverage (risk) Total liabilities divided by total assets 
Chih and Chih (2014), we define media tone (positive, negative and neutral) depending on the possible impact of media on the firm's stakeholders' wealth. A positive-tone article includes a narrative that has a favorable influence on stakeholders' wealth (improved performance, quality certifications, new strategic partners, mergers, investments, innovations or new projects). Conversely, a negative-tone article may negatively affect stakeholders' wealth (disposal of business units, layoffs, negative issues related to production, fraudulent practices, and directors' lawsuits). A neutral reporting tone means articles have neither a positive nor a negative tone. In the robustness tests, we replace media coverage with media tone scores and further analyze media tone as discussed in Section 7.3.

6.2.3 Control variables. Prior studies have provided empirical evidence for the association between governance variables (INEDs, board size, board meetings), firm-specific features (firm size, firm risk, profitability) and SD (García-Sánchez et al., 2011; Gallego-Álvarez et al., 2008; Gallego- Álvarez et al., 2011; Boubaker et al., 2011; Xiao et al., 2004; Hashim et al., 2014; Hassan, 2015a, 2015b). To remove the effect of governance and organizational features, we controlled for their confounding influences on the dependent variable (SD) in our regression models.

INEDs' effects on a firm's SD remain unclear. Hashim et al. (2014) and García-Sánchez et al. (2011) found that independent directors' effect on SD is not significant in Malaysia and Spain, while Hassan (2015a, 2015b) documented a negative influence of INEDs on SD in the UAE. Other studies have shown a negative link between frequency of board meetings and disclosure (Hassan, 2015a, 2015b), while others report no statistical relationship (García-Sánchez et al., 2011; Hashim et al., 2014). García-Sánchez et al. (2011) argued that frequent board meetings might reduce the volume of strategic information if the disclosed information negatively influences corporate competitive position, raises litigation risks, or leads to unfavorable stock price variation. As for board size, some studies have argued that large boards can overcome the lack of transparency characterizing smaller boards (John and Senbet, 1998; Cheng and Courtenay, 2006; Gandia, 2008; Adawi and Rwegasira, 2011; Hassan, 2015a, 2015b) and therefore may induce higher levels of SD (Hashim et al., 2014; Htay, 2012; Hassan, 2015a, 2015b).

Prior studies have documented that larger, highly leveraged or highly profitable firms tend to disclose more information (García-Sánchez et al., 2011; Gallego- Álvarez et al., 2008; Gallego- Álvarez et al., 2011; Boubaker et al., 2011; Xiao et al., 2004; Hashim et al., 2014; Hassan, 2015a, 2015b). Our study therefore controls for firm size (logarithm of total assets), firm risk measured by leverage (total debt divided by total assets) and firm profitability measured by return on equity (ROE).

\section{Results and discussion}

\subsection{Descriptive statistics}

Table III shows descriptive statistics of all variables. Average media coverage stands at 0.55 articles per year, a low figure compared to developed countries such as the US (Cahan et al., 2015). Considering media tone, the average for media favorability (0.26 articles per year) demonstrates the predominance of positive articles. In China, Wang and Ye (2015) reported a different pattern compared to that of the UAE. In China, average neutral media stands at 1.19 , average negative media at 0.43 , and average positive media at 0.25 . In the UAE, board size varies from 5 to 18 members, with a mean of 7.73 directors. Adawi and Rwegasira (2011) found a similar mean in the UAE in 2008, while Tejedo-Romero et al. (2017) reported a larger board size mean (15) in Spain. Table III shows that UAE nonfinancial listed firms have an average percentage of INEDs of 68 per cent, while the average number of board meetings is 6 . Table III shows lower profitability measured by ROE (0.04) compared to Adawi and Rwegasira (2011), who reported an average ROE of 16.96 in 2008 in the UAE. Table III also shows between and within variations of our sample 
Table III Descriptive statistics

Mean Minimum Maximum Standard deviation

VIF Overall

Between Within

\begin{tabular}{llllllll}
\hline SD index & 0.43 & 0.05 & 0.94 & 0.25 & 0.22 & 0.12 & \\
Media coverage & 0.55 & 0 & 4.43 & 0.93 & 0.77 & 0.57 & 2.56 \\
Negative media & 0.13 & 0 & 2.6 & 0.41 & 0.3 & 0.28 & 1.95 \\
Media tone & 0.26 & -1 & 1 & 0.44 & 0.26 & 0.36 & \\
INED & 0.68 & 0.2 & 1 & 0.23 & 0.21 & 0.09 & 1.06 \\
Board size & 7.73 & 5 & 18 & 2.07 & 1.88 & 0.86 & 1.17 \\
Board meetings & 6.55 & 3 & 17 & 1.65 & 1.3 & 1 & 1.21 \\
Leverage & 0.4 & 0.003 & 1.67 & 0.22 & 0.19 & 0.11 & 1.28 \\
Firm size & 7.64 & 3.93 & 11.77 & 1.68 & 1.6 & 0.27 & 1.98 \\
ROE & 0.04 & -3.29 & 1.82 & 0.29 & 0.16 & 0.25 & 1.07
\end{tabular}

governance, media, SD and control variables. It shows that governance variables (INED, board size and board meeting) have little variation within firms because these variables tend to be 'sticky', especially within emerging countries (Black et al., 2006; Esqueda and O'Connor, 2020).

Table IV presents the correlation matrix with the main variables. As predicted, the correlations between media measures and SD are positive. The correlation matrix does not exhibit a multicollinearity problem, since all correlation coefficients across variables are less than 0.70 . Nevertheless, high correlations are not a problem since each measure will be used separately in our regressions. VIF is another test for multicollinearity. Scholars suggest that VIF around two (Hassan, 2015a, 2015b) is accepted as a sign of no multicollinearity problem. Our regression models show a low statistic, even when using total media coverage and negative media in the same regression ( $\mathrm{VIF}=2.56)$.

\subsection{Regression results}

Table $V$ presents the diagnostic Hausman tests which confirm that random effects regressions provide more appropriate fit to our panel data set. However, because of the nature of data 'sticky data' as well as Husman test is significant at level of 10 per cent in some regressions, we opt for reporting both fixed effects and random effects regressions (Bell and Jones, 2015; Esqueda and O'Connor, 2020). Table $V$ displays both the fixed effects (FE) and the random effects (RE) regression results of the estimated models 1, 2, 3, 4 and 5. Model 1 is a benchmark model which includes the study control variables only. Model 2 adds the media coverage (total number of articles) to model 1. Model 3 incorporates both media coverage and negative media (total number of negative media) to

\begin{tabular}{|c|c|c|c|c|c|c|c|c|c|}
\hline & 1 & 2 & 3 & 4 & 5 & 6 & 7 & 8 & 9 \\
\hline 1. SD index & 1 & & & & & & & & \\
\hline 2. Media coverage & $0.36^{*}$ & 1 & & & & & & & \\
\hline 3. Negative media & $0.18^{*}$ & $0.69^{*}$ & 1 & & & & & & \\
\hline 4. Media tone & $0.31^{*}$ & $0.62^{*}$ & 0.05 & 1 & & & & & \\
\hline 5. INEDs & $0.12^{*}$ & $0.15^{*}$ & $0.09 *$ & $0.13^{*}$ & 1 & & & & \\
\hline 6. Board size & 0.06 & $0.18^{*}$ & $0.17^{*}$ & $0.12^{*}$ & $0.11^{*}$ & 1 & & & \\
\hline 7. Board meetings & $0.37^{*}$ & $0.23^{*}$ & $0.15^{*}$ & $0.18^{*}$ & 0.06 & -0.05 & 1 & & \\
\hline 8. Leverage & $0.24^{*}$ & $0.18^{*}$ & $0.14^{*}$ & $0.13^{*}$ & -0.01 & 0.03 & $0.32 *$ & 1 & \\
\hline 9. Firm size & $0.41^{*}$ & $0.6^{*}$ & $0.42^{*}$ & $0.39 *$ & $0.19^{*}$ & $0.36^{*}$ & $0.26^{*}$ & $0.36^{*}$ & 1 \\
\hline 10. ROE & -0.04 & 0.03 & -0.06 & 0.06 & -0.05 & -0.003 & $-0.15^{*}$ & $-0.17^{*}$ & -0.04 \\
\hline
\end{tabular}

Note: *Denotes significance at the 5 per cent level 


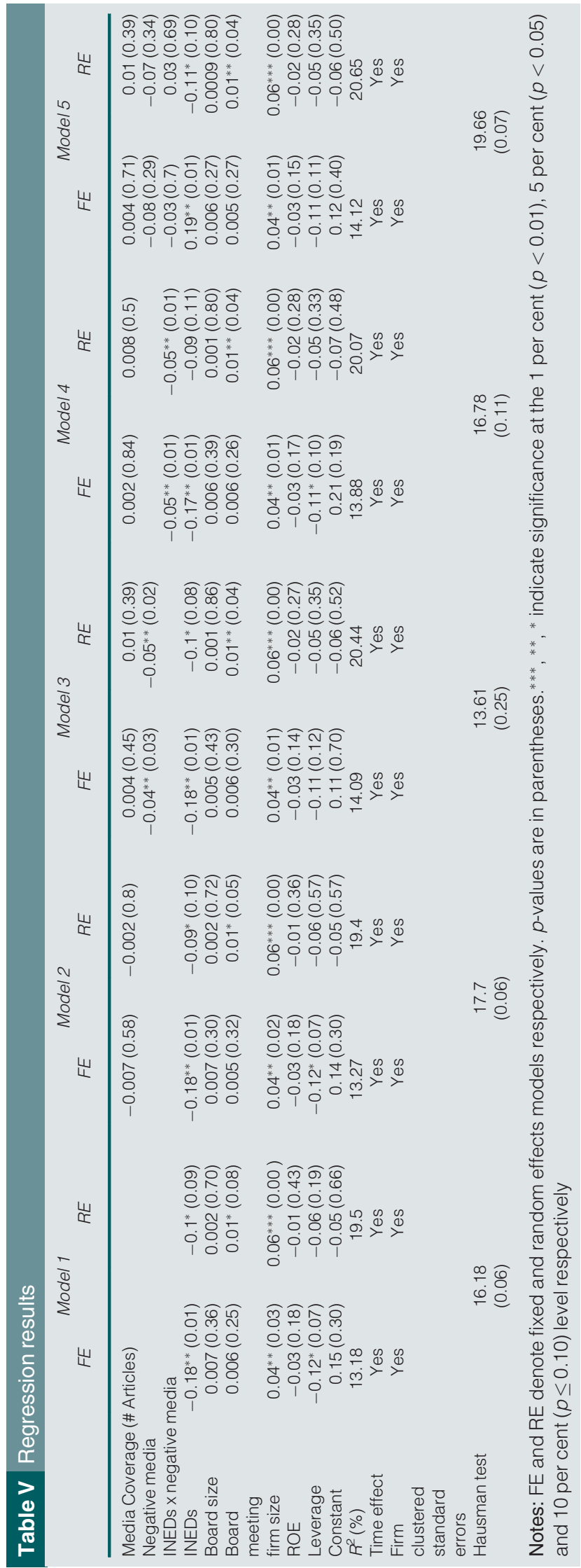


variables included in model 1 . Model 4 includes media coverage and the interaction variable (INEDs and negative media) to variables included in model 1. Model 5 regresses SD to the two sets of variables: media variables (media coverage, negative media and the moderating effect of INEDs on negative media) and control variables included in model 1. The reported $R^{2}$ ranges between 13.18 and 20.65 across all models.

Media coverage has no significant association with SD across all regression models, thereby rejecting H1. Our result contradicts Zaman et al. (2018) and Rupley et al. (2012), who reported a significant positive association between media coverage and corporate disclosure. Our results also refute our early predication that more media coverage reduces information asymmetry and creates public discourse, which in turn pressures firms to disclose higher levels of SD. Therefore, agency theory and media agenda-setting theory reasoning is not supported. Our $\mathrm{H} 1$ result, therefore, casts doubt on the role of corporate managers under intense media attention and whether media act as effective governance mechanism in emerging economies.

We also examined the effect of negative media coverage on SD in model 3. Unexpectedly, Model 3 shows a negative coefficient estimate (coefficient $=-0.05, p=0.02 \mathrm{RE}$ regression; coefficient $=-0.04, p=0.03 \mathrm{FE}$ regression) for the association between the volume of negative articles and $\mathrm{SD}$, rejecting $\mathrm{H} 2$. Our finding contradicts our prediction that firms disclose more strategic information under negative media coverage and agrees with Cuadrado-Ballesteros et al. (2014), who reported that under unfavorable media attention, municipalities tend to communicate less social responsibility information. The result indicates that corporate management decreases its level of SD under a high volume of negative media coverage. This implies that corporate managers are responsive and sensitive to unfavorable media coverage.

Once more, our $\mathrm{H} 2$ result disagrees with media agenda-setting theory and agency theory reasoning. Our results show that firms are likely to decrease SD under intense negative media coverage. A possible explanation is that the sample time frame followed the 2008 global financial crisis. We argue that media coverage following such unfavorable economic conditions may have led UAE firms to communicate less SD under growing adverse media attention. Another explanation is that firms may use their websites instead of annual reports to communicate strategic information and influence stakeholders' perceptions, as websites have wider dissemination (Campbell and Beck, 2004). Compared to García-Sánchez et al. (2011) and Hassan (2015a, 2015b) studies that extracted SD from companies' websites, our study extracts SD from UAE firms' annual reports.

Table $V$ reports a significant negative influence of INEDs on the volume of SD in annual reports at 10 per cent level of significance (in Models 1,2, 3 and 5 RE regressions) and at 5 per cent level of significance in all FE regressions. Our result contradicts prior studies reporting a positive effect of INEDs on SD (García-Sánchez et al., 2011; Hashim et al., 2014) and agrees with Hassan (2015a, 2015b), who revealed a negative influence of INEDs on SD in the UAE. A possible explanation for the negative relationship is that INEDs, due to time constraints resulting from their multi-directorship responsibilities, dedicate more effort to regulated disclosure than voluntary disclosure such as SD (cf. Zaman et al., 2018).

Model 4 shows a negative coefficient estimate (coefficient $=-0.05, p=0.01$ for both RF and FE regressions) for the association between the interaction variable (INEDs $x$ negative media) and SD. This implies that INEDs do not change their behavior under negative media coverage. INEDs are likely to reduce SD when their firms face negative publicity, therefore accepting H3. This result disagrees with García-Sánchez et al. (2011), who proposed that INEDs reveal more future-oriented strategic information to stakeholders to improve their personal reputation and chances of promotion to directorship positions. However, it agrees with Rupley et al. (2012), who reported that under negative media attention, INEDs are reluctant to provide more information to mitigate negative media coverage because they 
want to disassociate their names with unfavorable news that may affect their personal reputation.

Model 5 tests the effect of media variables (media coverage, negative media, and interaction variable [INEDs $x$ negative media]) in a single regression model on SD. It shows that media variables have an insignificant association with SD. In line with other models in Table VI, Model 5 shows a negative association between negative media and SD, confirming earlier results in Model 3.

Table $\mathrm{V}$ also reports findings for control variables (firm size, board size, frequency of board meetings, leverage, and profitability). The relationship between firm size and the extent of SD is significant across all regressions. Firm size drives the volume of SD. This result agrees with Hassan (2015a, 2015b), Garcia-Sanchez et al. (2014), Depoers (2000), Gallego-Álvarez et al. (2011), Cuadrado-Ballesteros et al. (2014), Rupley et al. (2012), and Padia and Yasseen (2011). Board size is not statistically significant in affecting SD at conventional levels for all models, yet frequency of board meetings is statistically significant and positively affects SD at 5 per cent and 10 per cent in RE regressions. More board meetings lead to more managerial discussion and openness to advocate SD. An active board (expressed by the number of board meetings) is likely to allocate more efforts/time to disclose more strategic information. Board meetings result is inconsistent with previous studies. Prior empirical findings show a negative association between board meetings and extent of SD (Hassan, 2015a, 2015b) while others showed no statistical relationship (Adawi and Rwegasira, 2011; Garcia-Sanchez et al., 2014; Hashim et al., 2014). We argue that this inconsistency is because of the differences in sample time frame, SD index items and whether SD is extracted from annual reports or corporate website.

Our results also show that leverage has no significant effect on SD under RE regressions, but has a significant effect under FE regressions at level of 10 per cent (Models 1, 2 and 4). Leverage results across all regressions (RF and FE) suggest that there is a little influence of the firm's level of debt on SD, which is consistent with previous studies (Htay, 2012; García-Sánchez et al., 2011). Profitability displays a nonsignificant effect on the level of SD in all models. These results are consistent with previous studies that reported a non-significant influence of profitability on voluntary disclosure (Rupley et al., 2012).

Table VI Robustness tests

\begin{tabular}{|c|c|c|c|c|c|c|}
\hline & \multicolumn{2}{|c|}{ Model 6} & \multicolumn{2}{|c|}{ Model 7} & \multicolumn{2}{|c|}{ Model 8} \\
\hline & $F E$ & $R E$ & $F E$ & $R E$ & $F E$ & $R E$ \\
\hline Media tone score & $0.007(0.67)$ & $0.01(0.42)$ & $-0.001(0.94)$ & $0.005(0.79)$ & $-0.001(0.9)$ & $0.007(0.7)$ \\
\hline Negative coverage & & & $-0.04^{* *}(0.03)$ & $-0.04 *(0.06)$ & & \\
\hline INEDs $\times$ Negative coverage & & & & & $-0.04^{* *}(0.01)$ & $-0.04^{* *}(0.04)$ \\
\hline INEDs & $-0.17^{* *}(0.01)$ & $-0.09(0.12)$ & $-0.18^{* *}(0.01)$ & $-0.1^{*}(0.09)$ & $-0.19^{* *}(0.01)$ & $-0.09(0.12)$ \\
\hline Board size & $0.007(0.29)$ & $0.001(0.77)$ & $0.005(0.25)$ & $0.001(0.87)$ & $0.005(0.42)$ & $0.001(0.84)$ \\
\hline Board meeting & $0.005(0.34)$ & $0.01 *(0.05)$ & $0.006(0.41)$ & $0.01^{* *}(0.03)$ & $0.006(0.25)$ & $0.01^{* *}(0.03)$ \\
\hline Leverage & $-0.12 *(0.07)$ & $-0.06(0.3)$ & $-0.11(0.11)$ & $-0.05(0.36)$ & $-0.11(0.10)$ & $-0.05(0.36)$ \\
\hline Firm size & $0.04^{* *}(0.02)$ & $0.06^{* * *}(0.00)$ & $0.04^{* *}(0.01)$ & $0.06^{* * *}(0.00)$ & $0.04 * *(0.01)$ & $0.06^{* * *}(0.00)$ \\
\hline ROE & $-0.03(0.13)$ & $-0.01(0.35)$ & $-0.03(0.15)$ & $-0.02(0.3)$ & $-0.03(0.15)$ & $-0.02(0.3)$ \\
\hline Constant & $0.24(0.16)$ & $-0.04(0.64)$ & $0.21(0.18)$ & $-0.08(0.38)$ & $0.22(0.19)$ & $-0.08(0.39)$ \\
\hline$R^{2}(\%)$ & 10.52 & 20.65 & 13.87 & 20.35 & 13.87 & 20.35 \\
\hline Time effect & Yes & Yes & Yes & Yes & Yes & Yes \\
\hline Firm clustered standard errors & Yes & Yes & Yes & Yes & Yes & Yes \\
\hline Hausman test & & & $\begin{array}{r}20 \\
(0.0\end{array}$ & & & \\
\hline
\end{tabular}

Notes: FE and RE denote fixed and random effects models respectively. $p$-values are in parentheses; ${ }^{* * *},{ }^{* *},{ }^{*}$ indicate significance at the 1 per cent $(p<0.01), 5$ per cent $(p<0.05)$ and 10 per cent $(p \leq 0.10)$ level respectively 


\subsection{Further analysis}

7.3.1. Robustness test. To corroborate our results, we replace media coverage with media tone, which measures overall media favorability tests. Following Cahan et al.,(2015), we calculate a media tone score per year for each firm as the total number of articles with a positive tone minus the total number of articles with a negative tone in year $t$, scaled by the total number of news articles in the same year. Media tone score ranges from -1 to 1 . Although the diagnostic Hausman tests (reported in Table VI) confirm that fixed effects regressions provide more appropriate fit to our panel data set for Models 6 and 8, we opt for running both fixed effects and random effects regressions in our robustness test. Table VI regressions confirm our original results for all variables across RF and FE regressions. It shows a significant negative association between SD and the interaction between INEDs and negative media (model 8). This implies that corporate INEDs are likely to reduce the level of SD in light of negative media. INEDs avoid reacting to unfavorable publicity because it could damage their reputation in the labor market. Table VI (Model 7) also shows a negative association between negative media and SD confirming our earlier results reported in Table V (Model 3).

7.3.2. Endogeneity test. To ensure nonexistence of the endogeneity problem in our regressions, we use the instrumental variables IV-GMM approach to examine the relation between media and SD. We rely on G2SLS random effects estimator to account for simultaneity, omitted variables, or measurement error in our regressors. Bednar (2012) addresses endogeneity by using firm size and industry performance as instruments for positive media coverage. Our study instrumental variables are: 1) the number of Google News items per year about the firm (expressed in logarithm) and the number of press articles reporting firm social activities for media coverage, and 2) the total Google News and number of articles reporting customers' dissatisfaction for negative media. Google News corresponds to the number of stories about a particular firm, including national, international, internet and press news.

Sargan-Hensen statistics (Table VII) reveal over-identified models with valid instruments. Table VII shows that regressions-based endogeneity assumption produces broadly similar results compared to random effects regressions in our original results. Table VII (Model 9) shows a negative relation between SD and media coverage simliar to our original regression model 2, yet media coverage is statistically insignificant at conventionnel levels. Likewise, Table VII (Models 9 and 10) confirms our original results for negative media- It shows a negative and significant relationship between SD and negative media coverage at 10 per cent significance level (Model 10).

\begin{tabular}{lcccc} 
Table VII Endogeneity results & Model 9 & & & \\
SD index & Coefficient & $p-v$ & $\begin{array}{c}\text { Model 10 } \\
\text { Coefficient }\end{array}$ & $p-v$ \\
\hline Media Coverage (\# Articles) & -0.03 & 0.22 & & \\
Negative coverage & & 0.04 & 0.09 \\
INEDs & -0.1 & 0.09 & -0.1 & 0.07 \\
Board size & 0.002 & 0.76 & 0.001 & 0.84 \\
Board meeting & 0.01 & 0.05 & 0.01 & 0.04 \\
Leverage & -0.06 & 0.26 & -0.05 & 0.33 \\
Firm size & 0.07 & 0.00 & 0.06 & 0.00 \\
ROE & -0.01 & 0.37 & -0.02 & 0.27 \\
$R^{2}$ & 17.26 & & 19.61 & \\
Year effect & Yes & & Yes & \\
Clustered standard errors & Yes & & Yes & \\
Sargan-Hansen statistic & 0.18 & 0.67 & 0.77 & 0.37
\end{tabular}


7.3.3 Reverse causality test. Because of the possiblity that SD may affect media, we examine the reverse causality. We use fixed and randam effects regressions to examine the reverse causality between media (as depedendent varibale) and corporate governance mechanisms and strategic disclosure level (as indpednent variables) as shown in Table VIII. Under RE regressions, Table VIII showes no association between SD and the media coverage (model 13: total number of articles having positive or negative tone) and negative media (model 14), yet it shows a significant positive association between SD and media tone at level of 10 per cent (model 12, RE, coefficient $=0.23, p=0.07$ ). Under FE regressions, Table VIII shows a negative association between SD and negative media at level of 10 per cent (coefficient $=-0.23, p=0.08$ in model 14) and no association with media tone (Model 12) and media coverage (model 13). Model 14 regressions' results, to large extent, reinforce our original results in Table V (model 3).

Table VIII RE regressions reveal a significant positive association between firm size and negative media (coefficient $=0.15, p$-value $=0.01$ ), media coverage (coefficient $=0.32, p$ value $=0.00$ ) and media tone (coefficient $=0.08, p$-value $=0.00$ ). Under FE regressions, firm size is significantly associated with negative media only (coefficient $=0.15, p$-value $=$ 0.05). Large firms are more visible and more likely to attract negative media attention.

Although our results suggest the reverse causality does not exist, models 13 and 14 findings suggest that firms can enhance their image in media by managing their strategic disclosure. Table VIII (model 12 RE and model $14 \mathrm{FE}$ ) provides evidence that firms' management manages the level of SD in light of media tone and level of negative media they face. The firm's SD activities seem to drive the media tone. Table VIII findings are aligned with impression management literature's perspective, which reflects managers' tendency to control firms' public activities (like SD) to drive media. We can argue, therefore, that firms' managers are likely to manage public impressions by managing the level of SD (Westphal et al., 2012). This issue of SD, media and impression management goes beyond the scope of the current study and represents an area for future research.

\section{Conclusion and future research}

Our study investigated the effect of media coverage and negative media tone on SD and whether INEDs have a moderating effect on the negative media tone-SD relationship for a sample of UAE listed non-financial firms for 2009-2016. Our study argues that media is a governance mechanism which not only shapes a firm's image but also builds public expectations and discourse about the firm's activities. Firms can manage expectations and

Table VIII Reverse causality regressions

\begin{tabular}{|c|c|c|c|c|c|c|}
\hline & \multicolumn{2}{|c|}{$\begin{array}{l}\text { Model } 12 \\
\text { Media tone }\end{array}$} & \multicolumn{2}{|c|}{$\begin{array}{c}\text { Model } 13 \\
\text { Media Coverage }\end{array}$} & \multicolumn{2}{|c|}{$\begin{array}{c}\text { Model } 14 \\
\text { Negative Media }\end{array}$} \\
\hline & $F E$ & $R E$ & $F E$ & $R E$ & $F E$ & $R E$ \\
\hline SD index & $0.07(0.67)$ & $0.23^{*}(0.07)$ & $-0.13(0.54)$ & $0.04(0.85)$ & $-0.23^{*}(0.08)$ & $-0.18(0.13)$ \\
\hline INEDs & $0.27(0.26)$ & $0.15(0.21)$ & $-0.05(0.9)$ & $0.06(0.82)$ & $-0.2(0.29)$ & $-0.1(0.4)$ \\
\hline Board size & $0.01(0.48)$ & $-0.0009(0.93)$ & $-0.02(0.69)$ & $-0.01(0.7)$ & $-0.03(0.16)$ & $-0.01(0.28)$ \\
\hline Board meeting & $-0.0008(0.97)$ & $0.008(0.59)$ & $0.05(0.2)$ & $0.04(0.15)$ & $0.02(0.16)$ & $0.02(0.22)$ \\
\hline firm size & $-0.01(0.8)$ & $0.08^{* * *}(0.00)$ & $0.22(0.13)$ & $0.32^{* * *}(0.00)$ & $0.15^{*}(0.05)$ & $0.15^{* *}(0.01)$ \\
\hline ROE & $0.04(0.78)$ & $0.12(0.33)$ & $-0.05(0.63)$ & $0.03(0.66)$ & $-0.05(0.44)$ & $-0.06(0.35)$ \\
\hline Leverage & $-0.166(0.36)$ & $-0.008(0.94)$ & $-0.05(0.13)$ & $0.009(0.97)$ & $0.25(0.12)$ & $0.15(0.17)$ \\
\hline$R^{2}(\%)$ & 4.11 & 24.79 & 41.6 & 45.55 & 16.4 & 18.92 \\
\hline Time effect & Yes & Yes & Yes & Yes & Yes & Yes \\
\hline Firm clustered standard errors & Yes & Yes & Yes & Yes & Yes & Yes \\
\hline Hausman test & \multicolumn{2}{|c|}{$8.4(0.58)$} & \multicolumn{2}{|c|}{$12.1(0.27)$} & \multicolumn{2}{|c|}{$15.1(0.12)$} \\
\hline
\end{tabular}

Notes: FE and RE denote fixed and random effects models respectively. $p$-values are in parentheses; ${ }^{* * *},{ }^{* *},{ }^{*}$ indicate significance at the 1 per cent $(p<0.01), 5$ per cent $(p<0.05)$ and 10 per cent $(p \leq 0.10)$ level respectively 
shape public discourse by adopting SD which is often associated with the firm's structure, especially board composition. Our study is the first to examine the moderating effect of INEDs on the association between media and SD. Our evidence shows no association between media coverage and SD and reveals that negative media tone is associated with $\mathrm{SD}$. When firms are exposed to a negative media tone, they reduce the level of SD in their annual reports. We can argue, therefore, that UAE firms adopt a conservative SD approach to maintain competitive advantage. UAE firms publish less SD under intense negative media. Our study results also show that INEDs encourage less SD and exhibit conservative behavior when associated with media tone. They do not play an active role when their firms face negative media as shown in Table V (model 4). This means that INEDs are careerconscious and likely to respond to negative press by becoming inactive to avoid damage to their personal reputation that may affect their prospects for future directorship positions.

Although our study only focuses on negative media tone only, it indirectly addresses positive and neutral media tones in the robustness test. Use of media tone score suggested by Cahan et al. (2015) provides a measure for tone favorability since it calculates media tone as the total number of articles with a positive tone minus the total number of articles with a negative tone in year $t$, scaled by total number of news articles in the same year. This measure coincides with Janis and Fadner's media tone coefficient (cf. Bansal and Clelland, 2004; Rupley et al., 2012). A comprehensive discussion and analysis of the pros and cons of the use of media tone scores goes beyond the scope of the current study and represents an area of future research.

Although the effect of board composition on firms' disclosure is well documented in the literature (Chandani and Mudiyanselage, 2018; Chong et al., 2018; Sundarasen and JeYen, 2016; Torchia and Calabro, 2016; Bueno et al., 2018), our study concentrates on a certain class of board members (i.e. INEDs). Firms' boards include different classes such as executive directors, independent directors and INEDs. Our study argues that INEDs are external professionals, stakeholders-oriented and have no other relationship with the firm (Rupley et al., 2012). INEDs have superior objectivity in monitoring the management behavior (Zaman et al., 2018), yet they are cautious to their reputations. Our study results show that INEDs want the firms in which they serve to avoid negative media by publishing less information, so they protect their professional reputations from damage.

Executive directors have relationships with the firm and therefore they are shareholdersoriented. They align their interests with shareholders' interests and therefore support the disclosure of information to reduce capital costs and risks perceived by investors (GarciaSanchez et al., 2014). Independent directors are less connected to the firm and therefore have greater objectivity in managing the firm's affairs compared to executive directors (Bueno et al., 2018). Board directors, therefore, are not homogeneous in terms of their competences and interests, and, consequently, these influence the effects of how boards perform. Our study shows that when media is considered, INEDs encourage less SD. Furthermore, they reinforce less disclosure when their firms face negative media attention. Our study examined the behavior of INEDs, yet the behavior of different classes of directors needs further investigation and represents an area for future research.

Our study reverse causality test provides evidence that firm management seems to manage the level of SD to avoid negative business press. Firms are more likely to disclose more strategic information to diminish the number of negative articles. The results are consistent with attention and impression management perspectives. Our study is informed by media agenda-setting theory and agency theory. Therefore, we encourage scholars to use impression management perspective to examine the relationship between media coverage, media tone and SD, while underscoring how different classes of directors (INEDs, executive and independent) behave under different media tones.

Our findings provide insights to policymakers and the business community. The study reveals the conservative role INEDs play when their firms face negative media coverage. 
This suggests that corporations should draft clear policies mandating the character of INEDs, who can protect the firm reputation under different types of media coverage. We encourage policymakers to draft business media codes highlighting the ethos underlying the use of media in business. A business media framework is an essential step to ensuring credibility in the media. Our findings may be relevant to countries other than the UAE, particularly those in the Gulf Cooperation Council and Middle East that share comparable social, political and economic contexts.

Our study has some limitations. It did not address the impact of the audit committee or the board diversity on SD. Although several studies document the effect of board diversity (i.e. age; gender, ethnicity and politically-connected directors) on the firm's disclosure (Kyaw et al., 2017; Chandani and Mudiyanselage, 2018; Chong et al., 2018; Bueno et al., 2018), scholars are yet to examine the effect of board diversity on SD. Furthermore, the influence of the interaction between diversified boards and media tone on the firm's disclosure is an appealing area for future research in emerging economics. Our study also did not examine the influence of social media on the firm's disclosure and performance (Tajvidi and Karami, 2017). Examining the association between social media and the firm's disclosure is another opportunity for future research. Finally, the study results are limited to a UAE context. However, insights related to the INEDs' moderating behavior apply to other contexts. Future research should focus on comparative studies examining the pattern of INEDs' moderating behavior across countries.

\section{References}

Adawi, M. and Rwegasira, K. (2011), "Corporate boards and voluntary implementation of best disclosure practices in emerging markets: evidence from the UAE listed companies in the Middle east", International Journal of Disclosure and Governance, Vol. 8 No. 3, pp. 272-293.

Ader, C.R. (1995), "A longitudinal study of agenda setting for the issue of environmental pollution", Journalism \& Mass Communication Quarterly, Vol. 72 No. 2, pp. 300-311.

Al Bawaba (2010), "Dubai media incorporated is media partner for the summit on the global agenda for third consecutive year", 22 November.

Al Bawaba (2017), "National media council reveals results of "public trust in UAE media" Study", 11 December.

Almatrooshi, S., Hussain, M. and Tehsin, M. (2018), "Role of public policies in promoting CSR: empirical evidence from business and civil society of UAE", corporate governance", Corporate Governance: The International Journal of Business in Society, Vol. 18 No. 6, pp. 1107-1123.

Aly, D., El-Halaby, S. and Hussainey, K. (2018), "Tone disclosure and financial performance: evidence from Egypt”, Accounting Research Journal, Vol. 31 No. 1, pp. 63-74.

Bansal, P. and Clelland, I. (2004), "Talking 'trash': legitimacy, impression management and unsystematic risk in the context of the natural environment", Academy of Management Journal, Vol. 47 No. 1, pp. 93-103.

Bartkus, B.R., Glassman, M. and Mcafee, R.B. (2002), "Do large european, japanese firms and US use their web sites to communicate their mission?", European Management Journal, Vol. 20 No. 4, pp. 423-429.

Baydoun, N., Maguire, W., Ryan, N. and Willett, R. (2013), "Corporate governance in five arabian countries", Managerial Auditing Journal, Vol. 28 No. 1, pp. 7-22.

Bednar, M.K. (2012), "Watchdog or lapdog? A behavioral view of the media as a corporate governance mechanism", Academy of Management Journal, Vol. 55 No. 1, pp. 131-150.

Bell, A. and Jones, K. (2015), "Explaining fixed effects: random effects modelling of time- series cross sectional and panel data", Political Science Research and Methods, Vol. 3 No. 1, pp. 133-153.

Bewley, K. and Li, Y. (2000), "Disclosure of environmental information by canadian manufacturing companies: a voluntary disclosure perspective", Advances in Environmental Accounting and Management, Vol. 1 No. 1, pp. 201-226. 
Black, B.S., Jang, H. and Kim, W. (2006), "Predicting firms' corporate governance choices: evidence from korea", Journal of Corporate Finance, Vol. 12 No. 3, pp. 660-691.

Boubaker, S., Lakhal, F. and Nekhili, M. (2011), "The determinants of web-based corporate reporting in France”, Managerial Auditing Journal, Vol. 27 No. 2, pp. 126-155.

Bueno, G., Marcon, R., Pruner-da-Silva, A. and Ribeirete, F. (2018), "The role of the board in voluntary disclosure", Corporate Governance: The International Journal of Business in Society, Vol. 18 No. 5, pp. 886-910.

Bushee, B.J., Core, J.E., Guay, W. and Hamm, S. (2010), "The role of the business press as an information intermediary", Journal of Accounting Research, Vol. 48 No. 1, pp. 1-19.

Byun, S.K. and Oh, J.M. (2018), "Local corporate social responsibility, media coverage and shareholder value", Journal of Banking \& Finance, Vol. 87, pp. 68-86.

Cahan, S.F., Chen, C., Chen, L. and Nguyen, N.H. (2015), "Corporate social responsibility and media coverage", Journal of Banking \& Finance, Vol. 59, pp. 409-422.

Campbell, D.J. (2000), "Legitimacy theory or managerial reality construction? Corporate social disclosure in marks and spencer plc corporate reports, 1969-1997", Accounting Forum, Vol. 24 No. 1, pp. 80-100.

Campbell, D. and Beck, A.C. (2004), "Answering allegations: the use of the corporate website for restorative ethical and social disclosure", Business Ethics: A European Review, Vol. 13 Nos 2/3, pp. 100-116.

Campbell, D., Shrives, P. and Bohmbach-Saager, H. (2001), "Voluntary disclosure of mission statements in corporate annual reports: signaling what and to whom?", Business and Society Review, Vol. 106 No. 1, pp. 65-87.

Carroll, C.E. and McCombs, M. (2003), "Agenda-setting effects of business news on the public's images and opinions about major corporations", Corporate Reputation Review, Vol. 6 No. 1, pp. 36-46.

Chandani, N. and Mudiyanselage, S. (2018), "Board involvement in corporate sustainability reporting: evidence from Sri Lanka", Corporate Governance: The International Journal of Business in Society, Vol. 18 No. 6, pp. 1042-1056.

Cheng, E.C.M. and Courtenay, S.M. (2006), "Board composition, regulatory regime and voluntary disclosure", The International Journal of Accounting, Vol. 41 No. 3, pp. 262-289.

Chih, H.-H. and Chih, H.-L. (2014), "Doing good with or without being known? Media coverage of corporate social performance and its impact on corporate financial performance", Managerial Finance, Vol. 40 No. 9, pp. 883-902.

Chong, L., Ong, H. and Tan, S. (2018), "Corporate risk-taking and performance in Malaysia: the effect of board composition, political connections and sustainability practices", Corporate Governance: The International Journal of Business in Society, Vol. 18 No. 4, pp. 635-654

Cuadrado-Ballesteros, B., Frías-Aceituno, J. and Martínez-Ferrero, J. (2014), "The role of media pressure on the disclosure of sustainability information by local governments", Online Information Review, Vol. 38 No. 1, pp. 114-135.

Dash, A. (2012), "Media impact on corporate governance in India: a research note", Corporate Governance: The International Journal of Business in Society, Vol. 12 No. 1, pp. 89-100.

Deegan, C. (2002), "The legitimizing effect of social and environmental disclosures - a theoretical foundation”, Accounting, Auditing \& Accountability Journal, Vol. 15 No. 3, pp. 282-311.

Deegan, C. and Brown, N. (1998), "The public disclosure of environmental performance information - a dual test of media agenda setting theory and legitimacy theory", Accounting and Business Research, Vol. 29 No. 1, pp. 21-41.

Deegan, C., Rankin, M. and Voght, P. (2000), "Firm's disclosure reactions to major social incidents: Australian evidence", Accounting Forum, Vol. 24 No. 1, pp. 101-130.

Depoers, F. (2000), "A cost-benefit study of voluntary disclosure: some empirical evidence from french listed companies", The European Accounting Review, Vol. 9 No. 2, pp. 245-263.

Du, X., Pei, H., Du, Y. and Zeng, Q. (2016), "Media coverage, family ownership, and corporate philanthropic giving: evidence from China", Journal of Management \& Organization, Vol. 22 No. 2, pp. 224-253. 
Dumay, J., Frost, G. and Beck, C. (2015), "Material legitimacy: blending organizational and stakeholder concerns through non-financial disclosures", Journal of Accounting \& Organizational Change, Vol. 11 No. 1, pp. 2-23.

Dyck, A., Volchkova, N. and Zingales, L. (2008), "The corporate governance role of the media: evidence from russia", The Journal of Finance, Vol. 63 No. 3, pp. 1093-1135.

Elijido-Ten, E. (2011), "Media coverage and voluntary environmental disclosures: a developing country exploratory experiment", Accounting Forum, Vol. 53 No. 3, pp. 139-157.

Esqueda, O. and O'Connor, T. (2020), "Corporate governance and lifecycles in emerging markets", Research in International Business and Finance, Vol. 51 (in press).

Gallego- Álvarez, I., García Sánchez, I.M. and Rodríguez-Domínguez, I. (2008), "Voluntary and compulsory information disclosed online: the effect of industry concentration and other explanatory factors", Online Information Review, Vol. 32 No. 5, pp. 596-622.

Gallego-Álvarez, I., Rodrıguez-Domínguez, L. and García-Sánchez, I.M. (2011), "Information disclosed online by Spanish universities: content and explanatory factors", Online Information Review, Vol. 35 No. 3 , pp. 360-385.

Gandia, J.L. (2008), "Determinants of interest-based corporate governance disclosure by spanish listed companies", Online Information Review, Vol. 32 No. 6, pp. 791-817.

Garcia, M. and Larrinaga, C. (2003), "Environmental disclosure in Spain: corporate characteristics and media exposure", Spanish Journal of Finance and Accounting/Revista Española de Financiación y Contabilidad, Vol. 115, pp. 184-214.

Garcia-Sanchez, I.M., Cuadrado-Ballesteros. and Sepulveda, C. (2014), "Does media pressure moderate CSR disclosures by external directors?", Management Decision, Vol. 52 No. 6, pp. 1014-1045.

García-Sánchez, I.M., Rodríguez-Domínguez, L. and Gallego-Álvarez, I. (2011), "Corporate governance and strategic information on the internet: a study of spanish listed companies", Accounting, Auditing and Accountability Journal, Vol. 24 No. 4, pp. 471-507.

Gulf News (2007), "Media reflects changing society", 1 November.

Hashim, M. F., Nawawi, A. and Salin, A. (2014), "Determinants of strategic information disclosure malaysian evidence", International Journal of Business and Society, Vol. 15 No. 3, pp. 547-572.

Hassan, M. K. (2015a), "Corporate governance, audit committee and the internet reporting of strategic information by UAE non-financial listed firms", Accounting and Management Information Systems, Vol. 14 No. 3, pp. 508-545.

Hassan, M. K. (2015b), "Corporate governance, organizational power and disclosures by firms in the United Arab Emirates", International Journal of Accounting, Auditing and Performance Evaluation, Vol. 11 Nos 3/4, pp. 281-311.

Hassan, M. K. (2012), "A disclosure index to measure the extent of corporate governance reporting by UAE listed corporations", Journal of Financial Reporting and Accounting, Vol. 10 No. 1, pp. 4-33.

Hassan, M. K. (2014), "Risk narrative disclosure strategies to enhance organizational legitimacy: evidence from UAE financial institutions", International Journal of Disclosure and Governance, Vol. 11 No. 1, pp. 1-17.

Hassan, M. K. (2018), "Governance, product market competition and agency costs: evidence from UAE", International Journal of Business Governance and Ethics, Vol. 13 No. 1, pp. 59-84.

Htay, S. N. N. (2012), "Corporate governance and strategic information disclosure in malaysian listed banks: panel data analysis", International Review of Business Research Papers, Vol. 8 No. 1, pp. 196-210.

Irvine, H. (2008), "The global institutionalization of financial reporting: the case of the UAE", Accounting Forum, Vol. 32 No. 2, pp. 125-142.

Islam, M. A. and Deegan, C. (2010), "Media pressures and corporate disclosure of social responsibility performance information: a study of two global clothing and sports retail companies", Accounting and Business Research, Vol. 40 No. 2, pp. 131-148.

John, J. (2006), "UAE plans code of corporate governance for listed firms", Khaleej Times, Vol. 8.

John, K. and Senbet, L.W. (1998), "Corporate governance and board effectiveness", Journal of Banking \& Finance, Vol. 22 No. 4, pp. 371-403.

Johnson, D. (2015), "Media freedom in the UAE", The National, 17 January. 
Kyaw, K., Olugbode, M. and Petracci, B. (2017), "Can board gender diversity promote corporate social performance", Corporate Governance: The International Journal of Business in Society, Vol. 17 No. 5 , pp. 789-802

Leuthesser, L. and Kohli, C. (2001), "Brand equity: capitalizing on intellectual capital", Ivey Business Journal, Vol. 65 No. 4, pp. 75-81.

Lim, S., Matolcsy, Z. and Chow, D. (2007), "The association between board composition and different types of voluntary disclosure”, European Accounting Review, Vol. 16 No. 3, pp. 555-583.

Lorsch, J. and Young, J. (1990), "Pawns or potentates: the reality of america's corporate boards", Academy of Management Perspectives, Vol. 4 No. 4, pp. 85-87.

Lui, B. and McConnell, J. J. (2013), "The role of the media in corporate governance: do the media influence managers' capital allocation decisions?", Journal of Financial Economics, Vol. 110 No. 1, pp. 1-17.

Meyer, J.W. and Rowan, B. (1977), "Institutionalized organizations: formal structure as myth and ceremony", American Journal of Sociology, Vol. 83 No. 2, pp. 340-363.

Milne, M. and Patten, D. (2002), "Securing organizational legitimacy: an experimental decision case examining the impact of environmental disclosures", Accounting, Auditing \& Accountability Journal, Vol. 15 No. 3, pp. 372-405.

Mobus, J. L. (2005), "Mandatory environmental disclosures in a legitimacy theory context", Accounting, Auditing and Accountability Journal, Vol. 18 No. 4, pp. 492-517.

National Media Council (2018), "UAE media council unveils regulations for electronic media", 6.

Nerlich, B. and Halliday, C. (2007), "Avian flu: the creation of expectations in the interplay between science and media", Sociology of Health \& IIIness, Vol. 29 No. 1, pp. 46-65.

O'Donovan, G. (2002), "Environmental disclosures in the annual reports: extending the applicability and predictive power of legitimacy theory", Accounting, Auditing \& Accountability Journal, Vol. 15 No. 3 , pp. 344-371.

Padia, N. and Yasseen, Y. (2011), "An examination of strategy disclosure in the annual reports of South African listed companies”, South African Journal of Business Management, Vol. 42 No. 3, pp. 27-35.

Patten, D. M. and Nance, J.R. (1998), "Regulatory cost effects in a good news environment: the intraindustry reaction to the alaskan oil spill", Journal of Accounting and Public Policy, Vol. 17 Nos 4/5, pp. 409-429.

Reverte, C. (2009), "Determinants of corporate social responsibility disclosure ratings by spanish listed firms", Journal of Business Ethics, Vol. 88 No. 2, pp. 351-366.

Rupley, K.H., Bown, D. and Marshall, R.S. (2012), "Governance, media and the quality of environmental disclosure", Journal of Accounting and Public Policy, Vol. 31 No. 6, pp. 610-640.

Santema, S., Hoekert, M., Van de Rijt, J. and Van Oijen, A. (2005), "Strategy disclosure in annual reports across Europe: a study on differences between five countries", European Business Review, Vol. 17 No. 4 , pp. 352-366

Santema, S. and Van de Rijt, J. (2001), "Strategy disclosure in dutch annual report", European Management Journal, Vol. 19 No. 1, pp. 101-108.

Shehata, N. (2015), "Development of corporate governance codes in GCC: an overview", Corporate Governance: The International Journal of Business in Society, Vol. 15 No. 3, pp. 315-338.

Suchman, M. C. (1995), "Managing legitimacy: strategic and institutional approaches", Academy of Management Review, Vol. 20 No. 3, pp. 571-610.

Sundarasen, S. and Je-Yen, T. (2016), "Board composition and corporate social responsibility in an emerging market", Corporate Governance: The International Journal of Business in Society, Vol. 16 No. 1, pp. 35-53.

Tajvidi, R. and Karami, A. (2017), "The effect of social media on firm performance", Computers in Human Behavior, pp. 1-10.

Tejedo-Romero, F., Rodrigues, L.L. and Craig, R. (2017), "Women directors and disclosure of intellectual capital information", European Research on Management and Business Economics, Vol. 23 No. 3, pp. 123-131. 
Torchia, M. and Calabro, A. (2016), "Board of directors and financial transparency and disclosure. evidence from Italy", Corporate Governance: The International Journal of Business in Society, Vol. 16 No. 3, pp. 593-608.

Wang, J. and Ye, K. (2015), "Coverage and firm valuation: evidence from China", Journal of Business Ethics, Vol. 127 No. 3, pp. 501-511.

Watson, S. (2011), "Conflict diamonds, legitimacy and media agenda: an examination of annual report disclosures", Meditari Accountancy Research, Vol. 19 Nos 1/2, pp. 94-111.

Westphal, J. D., Park, S. H., McDonald, M. L. and Hayward, M. L. A. (2012), "Helping other CEOs avoid bad press: social exchange and impression management support among CEOs in communications with journalists", Administrative Science Quarterly, Vol. 57 No. 2, pp. 217-268.

World Bank (2016), World Bank Governance Indicators.

World Bank Ease of Doing Business Report (2017).

World Economic Forum's Global competitiveness report. (2017-2018)

Xiao, J.Z., Yang, H. and Chow, C.W. (2004), "The determinants and characteristics of voluntary internetbased disclosures by listed chinese companies", Journal of Accounting and Public Policy, Vol. 23 No. 3 , pp. 191-225.

Yekini, K.C., Adelopo, I. and Adegbite, E. (2017), "The impact of community expectations on corporate community involvement disclosures in the UK", Accounting Forum, Vol. 41 No. 3, pp. 234-252.

Zaman, R., Bahadar, S., Kayani, U. N. and Arslan, M. (2018), "Role of media and independent directors in corporate transparency and disclosure: evidence from an emerging economy", Corporate Governance: The International Journal of Business in Society, Vol. 18 No. 5, pp. 858-885.

\section{Further reading}

Bardsley, D. (2015), "Media freedom in the UAE", The National, Vol. 17.

International Monetary Fund (2017), World Economic Outlook, October.

Khaleej Times (2017), "More women to get board positions in UAE firms", 11.

Leuthesser, L. and Kohli, C. (1997), "Corporate identity: the role of mission statements", Business Horizons, Vol. 40 No. 3, pp. 59-66.

UAE code of governance: Securities and Commodities Authority Chairperson (2007), Decision No. (R/23) on Corporate Governance Code for Joint-Stock Companies and Institutional Discipline Criteria: amended by decision 518 of 2009 . 
Table Al Percentage of firms disclosing SD items per year

Strategic disclosure items

2009

$2010 \quad 2011$

2012

2013

2014

20152016

1. Company's objectives, mission and philosophy

19.23

21.15

15.38

15.38

13.46

19.23

$21.15 \quad 23.08$

2. Strategic alliances

$\begin{array}{lll}61.54 & 69.23 & 55.77\end{array}$

65.38

71.15

78.85

$78.85 \quad 86.54$

$\begin{array}{lll}13.46 & 25.00 & 11.54\end{array}$

21.15

15.38

25.00

$25.00 \quad 25.00$

4. Company's strategic planning (expansion, markets, regions)

5. Annual planning/performance against targets/graphs

57.69

6.15

44.23

51.92

59.62

$55.77 \quad 67.31$

6. Description of the competition context

28.85

38.46

21.15

38.46

42.31

51.92

$50.00 \quad 59.62$

7. Risk control and management governance

75.00

90.38

71.15

$25.00 \quad 25.00$

$75.00 \quad 90.38$

73.08

9. Production processes information

30.77

32.69

17.31

23.08

30.77

82.69

82.69

36.54

$40.38 \quad 50.00$

10. Strategic business unit

$\begin{array}{ll}3.85 & 5.77\end{array}$

25.00

32.69

86.54

100.00

$100.00 \quad 94.23$

$19.23 \quad 15.38$

$25.00 \quad 26.92$

3.85

21.15

42.31

100.00

$100.00 \quad 98.08$

11. Weakness and threats

$11.54 \quad 15.38$

$\begin{array}{ll}17.00 & 34.62\end{array}$

5.77

21.15

36.54
26.92

$38.46 \quad 38.46$

13. Information on cost-effective strategy

7.69

7.69

$25.00 \quad 21.15$

14. Information on innovative approaches

15. Health, safety and environment strategy

$19.23 \quad 38.46$

13.46

13.46

21.15

21.15

$9.62 \quad 5.77$

16. Strategy towards workforces and their benefits

$73.08 \quad 78.85$

21.15

25.00

30.77

34.62

26.92

38.46

32.69

17. Firm's customer groups

$25.00 \quad 36.54$

$30.77-30.77$

23.08

15.38

21.15

$26.92 \quad 32.69$

$\begin{array}{lll}96.15 & 94.23 & 98.08 \\ 40.38 & 36.54 & 59.62\end{array}$

\section{Corresponding author}

Mostafa Kamal Hassan can be contacted at: mostafa.hassan@qu.edu.qa

For instructions on how to order reprints of this article, please visit our website:

www.emeraldgrouppublishing.com/licensing/reprints.htm

Or contact us for further details: permissions@emeraldinsight.com 